DOI: 10.46340/eppd.2020.7.2.43

Ольга Якимчук

Національний університет "Острозька академія», Україна

ОСОБА ПРЕДСТАВНИКА ЮРИДИЧНОЇ ОСОБИ У КРИМІНАЛЬНОМУ ПРОВАДЖЕННІ УКРАЇНИ

\author{
Olha Yakymchuk \\ ORCID ID: https://orcid.org/0000-0002-3545-1165 \\ National University of Ostroh Academy, Ukraine
}

\title{
THE REPRESENTATIVE OF A LEGAL ENTITY IN CRIMINAL PROCEEDINGS OF UKRAINE
}

The article analyzes the legal entity's representative in criminal proceedings in Ukraine. In the article, the author finds out the peculiarities of representation of a legal entity by its head, employee, advocate, and other persons authorized by law or founding documents. Also, the author explores the basic requirements that are set for a representative in criminal proceedings. The author focuses on the problem of self-representation by a legal entity in criminal proceedings according to the latest legislative amendments. Moreover, certain shortcomings have been identified in the legal regulation of representation of legal entities in criminal proceedings, in particular, the lack of unification of the rules which are regulating the representation with civil procedure, economic procedure, and administrative legislation. Proposals are recommended to amend the current legislation of Ukraine.

Keywords: advocate, criminal proceedings, advocacy monopoly, representative of a legal entity, self-representation of a legal entity.

Постановка проблеми. Юридична особа є суб'єктом кримінально-процесуальної діяльності. Вона реалізує свої процесуальні права та виконує процесуальні обов'язки через інститут представництва. Процесуальний статус представників юридичних осіб у кримінальному праві регулюється кримінально-процесуальним, цивільним, господарським, трудовим та цивільнопроцесуальним законодавством.

Кримінально-процесуальний кодекс України (далі - КПК України) чітко встановлює перелік осіб, які можуть здійснювати представництво юридичної особи у кримінальному провадженні України. Так, представником юридичної особи учасника кримінального провадження, у всіх можливих для юридичної особи процесуальних статусах (потерпілого, цивільного позивача, цивільного відповідача, особи, щодо якої здійснюється провадження тощо) може бути або особа, яка у кримінальному провадженні має право бути захисником (адвокат), або керівник чи інша особа, уповноважена законом або установчими документами, або працівник юридичної особи (ст. ст. 58, 60, $63,64^{1}, 64^{2}$ КПК України). У виняткових випадках, представником юридичної особи в інтересах держави може виступати прокурор (ст. 36 КПК України).

На відміну, від інших видів процесуальних представництв, кримінально-процесуальне представництво здійснюється не лише на стадії судового розгляду, але й на стадії досудового розслідування. 3 прийняттям 02 червня 2016 Закону України «Про внесення змін до Конституції України (щодо правосуддя)», яким фактично було введено монополію адвокатури на представництво інтересів іншої особи у суді (ст. $131^{2}$ Конституції України), було обмежено перелік осіб, які можуть здійснювати представництво юридичних осіб у суді в рамках кримінального провадження. Однак, вже 29 грудня 2019 року набрав чинності Закон України «Про внесення змін до деяких законодавчих актів України щодо розширення можливостей самопредставництва в суді органів державної влади, органів влади Автономної Республіки Крим, органів місцевого самоврядування, інших юридичних осіб незалежно від порядку їх стоврення», яким було розширено поняття «самопредставництво юридичної особи» та фактично проігноровані конституційні зміни щодо монополії адвокатури відносно юридичних осіб. Наразі, вже є роз'яснення Касаційного цивільного та Касаційного 
господарського судів Верховного Суду щодо самопредставництва юридичної особи, однак досі не має сформованої думки Касаційного кримінального суду. Таким чином, актуальним вбачається розглянути питання хто саме може бути представником юридичної особи у кримінальному провадженні, яке особливо гостро постає сьогодні в українському суспільстві.

Виклад основного матеріалу. Представник, в тому числі представник юридичної особи у кримінальному провадженні, $є$ самостійним учасником кримінального провадженні на рівні 3 іншими учасниками. У визначенні сторін кримінального провадження (п. 19 ч. 1 ст. 3 КПК України), учасників кримінального провадження (п. 25 ч. 1 ст. 3 КПК України) та учасників судового провадження (п. 26 ч. 1 ст. 3 КПК України) представник зазначається поряд, на рівні з іншими особами, яких він представляє. На самостійності наголошує також В. Г. Асташенков відмічаючи, що «в кримінальному процесі з моменту вступу в справу представник $\epsilon$ самостійним рівноправним учасником, а тому права та обов'язки представника в момент їх виникнення не можуть вважатися належними особі, яку він представляє, а належать представнику» ${ }^{1}$. А тому, представник юридичної особи як учасник кримінального провадження повинен відповідати певним вимогам, які встановлені законодавцем, аби набути процесуального статусу представника.

Перш за все, представляти законні інтереси учасників кримінального провадження може лише фізична та дієздатна особа. Вимоги до дієздатності встановлені статтею 30 Цивільного кодексу України і визначаються як здатність фізичної особи «своїми діями набувати для себе цивільних прав і самостійно їх здійснювати, а також здатність своїми діями створювати для себе цивільні обов'язки, самостійно їх виконувати та нести відповідальність у разі їх невиконання»². Окрім того, очевидно, що представник повинен бути повнолітнім.

Законодавством також встановлюються обмеження для представників - певні обставини, які можуть стати підставою для відводу представника. Так, ст. 78 КПК України встановлено, що представник не повинен брати участь «у цьому ж кримінальному провадженні як слідчий суддя, суддя, присяжний, прокурор, слідчий, потерпілий, цивільний позивач, цивільний відповідач, експерт, спеціаліст, представник персоналу органу пробації, перекладач» ${ }^{3}$. Окрім того, не повинно існувати конфлікту інтересів: представник не повинен «у цьому провадженні надавати правову допомогу особі, інтереси якої суперечать інтересам особи, яка звернулася з проханням про надання правової допомоги» ${ }^{4}$. Встановлюються вимоги й щодо родинних зв'язків: представник не може бути «близьким родичем або членом сім'ї слідчого, прокурора, потерпілого або будь-кого із складу суду» 5 .

Разом з тим, кримінальне процесуальне законодавство, окрім загальних цивільно-правових вимог, встановлює перелік осіб, які можуть бути представниками у кримінальному провадженні залежно від кримінально-процесуального статусу юридичної особи (ст. ст. 58, 60, 63, 64 ${ }^{1}, 64^{2}$ КПК України).

Представником юридичної особи на всіх стадіях кримінального провадженні може бути особа, яка у кримінальному провадженні має право бути захисником, тобто адвокатом (ст. 45 КПК України). Адвокатом може бути фізична особа, яка має повну вищу юридичну освіту, володіє державною мовою, має стаж роботи в галузі права не менше двох років, склала кваліфікаційний іспит, пройшла стажування, склала присягу адвоката України та отримала свідоцтво про право на зайняття адвокатською діяльністю. Аби здійснювати представництво юридичних осіб у кримінальному провадженні адвокат повинен мати чинне свідоцтво про право на зайняття адвокатською діяльністю (п. 2 ч. 2 ст. 78 КПК України). Окрім того, відомості про адвоката повинні бути внесено до Сдиного реєстру адвокатів України та відсутні дані про зупинення або припинення права на зайняття адвокатською діяльністю (ст. 45 КПК України).

\footnotetext{
${ }^{1}$ Асташенков, В.Г. (1969). O расширении процессуальных гарантий участников уголовно-процессуальной деятельности при окончании предварительного следствия. Учение записки Саратовского юридического Института, 191.

${ }^{2}$ Цивільний кодекс України 2003 (Верховна Рада Україна). Офіиійний сайт Верховної Ради Украӥни. $<$ http://zakon0.rada.gov.ua/laws/show/435-15> (2020, березень, 05).

${ }^{3}$ Кримінальний процесуальний кодекс Украйни 2012 (Верховна Рада України). Офіційний сайт Верховної Ради України. <http://zakon2.rada.gov.ua/laws/show/4651-17> (2020, березень, 05).

${ }^{4}$ Кримінальний процесуальний кодекс Украӥни 2012 (Верховна Рада України). Офіційний сайт Верховної Ради України. <http://zakon2.rada.gov.ua/laws/show/4651-17> (2020, березень, 05).

${ }^{5}$ Кримінальний проиесуальний кодекс Украӥни 2012 (Верховна Рада України). Офіційний сайт Верховної Ради України. <http://zakon2.rada.gov.ua/laws/show/4651-17> (2020, березень, 05).
} 
Із введенням монополії адвокатури на представництво інтересів інших осіб у суді (застосовується у судах касаційної інстанції 31 січня 2017 року, у судах апеляційної інстанції 31 січня 2018 року, у судах першої інстанції з 1 січня 2019 року та для представників органів державної влади та органів місцевого самоврядування у всіх судах 31 січня 2020 року), представниками юридичних осіб у кримінальному провадженні на стадії судового провадження фактично можуть бути лише адвокати. Разом з тим, законом не заборонено представникам без адвокатського посвідчення представляти інтереси юридичної особи на досудовому розслідуванні. Слід відмітити, що монополія адвокатури на представництво у судах застосовувалась би до юридичних осіб у повному обсязі та заперечувала би положення ст. ст. 58, 60, 63, $64^{1}, 64^{2}$ КПК України щодо представництва юридичних осіб у кримінальному провадження іншими особами (керівником, працівником юридичної особи або іншою особою уповноваженою законом або установчими документами), якби не існувало поняття «самопредставництва юридичної особи».

Відповідно до ч. 3 ст. 58 Цивільного процесуального кодексу України, ч. 3 ст. 56 Господарського процесуального кодексу України, ч. 3 ст. 55 Кодексу адміністративного судочинства України юридична особа бере участь у справі через свого керівника або члена виконавчого органу, уповноваженого діяти від іії імені відповідно до закону, статуту, положення (самопредставництво юридичної особи), або через представника. 29 грудня 2019 року Законом України «Про внесення змін до деяких законодавчих актів України щодо розширення можливостей самопредставництва в суді органів державної влади, органів влади Автономної Республіки Крим, органів місцевого самоврядування, інших юридичних осіб незалежно від порядку їх створення» уточнено поняття «самопредставництво юридичної особи», внесено відповідні зміни у вищезазначені процесуальні кодекси України: «юридична особа незалежно від порядку її створення бере участь у справі через свого керівника, члена виконавчого органу, іншу особу, уповноважену діяти від ії імені відповідно до закону, статуту, положення, трудового договору (контракту) (самопредставництво юридичної особи), або через представника ${ }^{1} »$. Таким чином, до самопредставництва юридичної особи було включено представництво працівником юридичної особи.

Однак, законодавцем було проігноровано внесення відповідних змін щодо самопредставництва юридичних осіб у КПК України, хоча юридичні особи є самостійними учасниками кримінального провадження України. Таким чином, як і до прийняття Закону України «Про внесення змін до деяких законодавчих актів України щодо розширення можливостей самопредставництва в суді органів державної влади, органів влади Автономної Республіки Крим, органів місцевого самоврядування, інших юридичних осіб незалежно від порядку їх стоврення» так і після, КПК України не містить жодних положень про самопредставництво юридичної особи. Проте, навіть за відсутності положень про самопредставництво юридичних осіб у КПК України, доцільним вбачається застосування судами за аналогією цивільно-процесуального законодавства щодо допуску керівників, працівників, інших осіб уповноважених законом або установчими документами, без статусу адвоката до представництва юридичних осіб у кримінальному провадження на стадії судового розгляду, оскільки по-перше, КПК України містить положення, якими передбачається надання кримінально-процесуального статусу представника таким особам (ст. ст. 58, 60, 63, 64 ${ }^{1}, 64^{2}$ КПК України), по-друге, у кримінальному провадженні, в якому було подано цивільний позов, до процесуальних відносин, що виникли у зв'язку з цивільним позовом та які не врегульовані КПК України, можуть застосовуватися норми Цивільного процесуального кодексу України за умови, що вони не суперечать засадам кримінального судочинства (п. 5 ст. 128 КПК України).

Окрім адвоката, представником юридичної особи у кримінальному провадженні згідно положень КПК України може бути працівник юридичної особи. Особливістю цього представництва $\epsilon$ те, що представник перебуває у трудових відносинах із особою, яку представляє та його діяльність додатково регулюється нормами трудового законодавства. На відміну самопредставництва юридичної особи працівником у цивільному, господарському процесах та у порядку адміністративного судочинства, у кримінальному провадженні працівник юридичної особи здійснює представництво за довіреністю.

1 Закон Украӥни «Про внесення змін до деяких законодавчих актів Украӥни щзодо розщирення можливостей самопредставництва в суді органів державної влади, органів влади Автономної Республіки Крим, органів місиевого самоврядування, інших юридичних осіб незалежно від порядку їх створення» 2019 (Верховна Рада України). Офіиійний сайт Верховної Ради України. <https://zakon.rada.gov.ua/laws/show/390-20> (2020, березень, 06). 
Кримінально-процесуальне законодавство не встановлює вимог щодо спеціальної юридичної освіти працівника-представника, однак, зазвичай, представляють інтереси роботодавця (юридичної особи) працівники юридичної служби - юрисконсульти. Функції юридичної служби може виконувати й один юрисконсульт. На державних підприємствах, установах, організаціях, державних органах створюється юридична служба. Ї̈̈ функціонування регулюється Постановою Кабінету Міністрів України № 1040 від 26 листопада 2008 р. «Про затвердження Загального положення про юридичну службу міністерства, іншого органу виконавчої влади, державного підприємства, установи та організації». Так, відповідно до п. 2 ч. 2 цієї постанови «для представлення інтересів держави в судах під час розгляду справ, стороною або третьою особою в яких $є$ органи виконавчої влади, у складі юридичної служби утворюється відповідний підрозділ або такі повноваження надаються окремій посадовій особі» ${ }^{1}$.

Ще одним представником юридичної особи у кримінальному провадженні може бути керівник юридичної особи, уповноважений на те установчими документами юридичної особи. Керівник юридичної особи, як і працівник юридичної особи перебувають у трудових відносинах із юридичною особою, проте для здійснення представництва керівнику не потрібна довіреність. Необхідно зазначити, що установчими документами можна уповноважити будь-яку іншу особу. При цьому, законодавством не висунуто жодних вимог щодо перебування такої особи у трудових відносинах із юридичною особою. Такою особою може бути й засновник юридичної особи, акціонер, член наглядової ради тощо.

Окрім особи, уповноваженої установчими документами, представником юридичної особи може бути особа, уповноважена на те законом. До цієї категорії представників юридичної особи слід віднести арбітражного керуючого (розпорядника майна, керуючого санацією або ліквідатора). Представництво юридичних осіб ліквідатором у кримінальному провадженні можливо тоді, коли юридична особа ліквідується та повноваження керівника були передані ліквідаційній комісії або ліквідатору (ст. 105 ЦК України) або коли юридична особа припиняє свою діяльність в порядку визнання банкрутом (Кодекс України з процедур банкрутства).

До представництва арбітражними керуючими, окрім загальних вимог встановлених КПК України, господарським законодавством передбачено також спеціальні вимоги. Так, арбітражним керуючим є «фізична особа, яка отримала відповідне свідоцтво та інформація про яку внесена до Єдиного реєстру арбітражних керуючих України ${ }^{2}$. Окрім того, така особа призначається господарським судом у встановленому порядку в справі про банкрутство як керуючий санацією або ліквідатор. Арбітражний керуючий з моменту постановлення ухвали (постанови) про призначення його керуючим санацією або ліквідатором до моменту припинення здійснення ним повноважень прирівнюється до службової особи підприємства-боржника (п. 2 ст. 10 Кодексу України з процедур банкрутства), а також може виконувати обов'язки керівника такої юридичної особи (п. 2 ст. 40, ч. 8 п. 1 ст. 59 Кодексу України з процедур банкрутства).

Також слід зазначити, що представником юридичної особи у кримінальному провадженні у окремих випадках може бути прокурор. Так, п. 12 ст. 36 КПК України наділяє прокурора правом пред’явити цивільний позов в інтересах держави. Законом України «Про прокуратуру» встановлюються випадки, коли прокурор виконує представницькі функції. Так, ст. 23 цього закону встановлюється, що прокурор здійснює представництво у суді державних інтересів лише у випадку, коли «захист цих інтересів не здійснює або неналежним чином здійснює орган державної влади, орган місцевого самоврядування чи інший суб'єкт владних повноважень, до компетенції якого віднесені відповідні повноваження, а також у разі відсутності такого органу»³. Окрім того, встановлюються випадки, коли таке представництво не здійснюється: захист інтересів державних компаній, а також «у правовідносинах, пов'язаних із виборчим процесом, проведенням референдумів, діяльністю

\footnotetext{
${ }^{1}$ Постанова про затвердження Загального положення про юридичну службу міністерства, іншого органу виконавчої влади, державного підприємства, установи та організації 2008 (Кабінет Міністрів України). Офіиіийний сайт Верховної Ради України. <http://zakon5.rada.gov.ua/laws/show/1040-2008-\%D0\%BF> (2020, березень, 06).

${ }^{2}$ Кодекс Украйни з прочедур банкрутства 2018 (Верховна Рада України). Офіційний сайт Верховної Ради України. <https://zakon.rada.gov.ua/laws/show/2597-19> (2020, березень, 05).

3 Закон про прокуратуру 2014 (Верховна Рада України). Офіиійний сайт Верховної Ради України.

$<$ http://zakon.rada.gov.ua/laws/show/1697-18> (2020, березень, 05).
} 
Верховної Ради України, Президента України, створенням та діяльністю засобів масової інформації, а також політичних партій, релігійних організацій, організацій, що здійснюють професійне самоврядування, та інших громадських об'єднань» ${ }^{1}$.

Прокурор $є$ представником юридичної особи у кримінально-процесуальному статусі потерпілого або цивільного позивача. Д. К. Боков визначає пред'явлення цивільного позову прокурором у кримінальному провадженні як «виражену у встановленій процесуальній формі вимогу прокурора на захист інтересів фізичних і юридичних осіб, які зазнали майнової чи моральної шкоди від кримінального правопорушення, до підозрюваного, обвинуваченого, підсудного, засудженого чи інших осіб, які несуть майнову відповідальність за їхні дії, про відшкодування цієї шкоди, заявлена до суду та розглядувана спільно з кримінальним провадженням або в порядку цивільного судочинства» ${ }^{2}$.

Особливістю представництва юридичних осіб прокурором в загальному та зокрема у кримінальному провадженні, $є$ спрямованість захисту інтересів не на конкретних юридичних осіб (державних органів, суб'єктів владних повноважень чи органів місцевого самоврядування), а держави в цілому.

Висновок. Юридичні особи дедалі частіше та активніше беруть участь у кримінальному провадженні України, однак досі кримінально-процесуальне законодавство недостатньо регулює їх участь у процесі, порівняно із цивільним, господарським процесами та адміністративним судочинством. Юридичні особи беруть участь у кримінальному провадженні через своїх представників. Представником юридичної особи у кримінальному провадженні може бути адвокат, іiі керівник або інша особа, уповноважена установчими документами або законом та працівник юридичної особи за довіреністю. В окремих, передбачених законом випадках, представником юридичної особи у кримінальному провадженні може бути прокурор. У зв'язку із введенням монополії адвокатури на представництво у суді, потребує роз'яснення в рамках КПК України положення щодо самопредставництва юридичних осіб на зразок положень включених у інші процесуальні кодекси України, оскільки КПК України оперує лише поняттям «представник», а поняття «самопредставництво юридичної особи» взагалі відсутнє.

Відсутність у кримінально-процесуальному законодавстві України поняття «самопредставництво юридичної особи» створює колізію управового просторі України, які не сприяють здійсненню верховенства права та доступу до правосуддя. Отож, необхідним вбачається внесення змін до ст. ст. 58, 63, $64^{1}, 64^{2}$ КПК України, що місять положення щодо представництва юридичної особи та викладення їх в уніфікованій із цивільним, господарським процесами.

\section{References:}

1. Astashenkov, V.G. (1969). O rasshirenii protsessualnyih garantiy uchastnikov ugolovno-protsessualnoy deyatelnosti pri okonchanii predvaritelnogo sledstviya [ On the expansion of procedural guarantees of participants in criminal procedural activities at the end of the preliminary investigation]. Uchenie zapiski Saratovskogo yuridicheskogo Instituta [Teaching notes of the Saratov Law Institute], no. 16, 190-192. [in Russian].

2. Tsyvilnyi kodeks Ukrainy 2003 [Civil Code] (Verkhovna Rada Ukrainy) [Verkhovna Rada of Ukraine]. Ofitsiinyj sajt Verkhovnyi Rady Ukrainy [The official website of the Verkhovna Rada of Ukraine]. $<$ http://zakon0.rada.gov.ua/laws/show/435-15> (2020, March, 05). [in Ukrainian].

3. Kryminalnyi protsesualnyi kodeks Ukrainy 2012 [Criminal Procedure of Ukraine] (Verkhovna Rada Ukrainy) [(Verkhovna Rada of Ukraine)]. Ofitsiinyj sajt Verkhovnoyi Rady Ukrainy [The official website of the Verkhovna Rada of Ukraine]. <http://zakon2.rada.gov.ua/laws/show/4651-17> (2020, March, 05). [in Ukrainian].

4. Zakon Ukrainy pro vnesennia zmin do deiakykh zakonodavchykh aktiv Ukrainy shchodo rozshyrennia mozhlyvostei samopredstavnytstva v sudi orhaniv derzhavnoi vlady, orhaniv vlady Avtonomnoi Respubliky Krym, orhaniv mistsevoho samovriaduvannia, inshykh yurydychnykh osib nezalezhno vid poriadku yikh stvorennia 2019 [Law of Ukraine On Amendments to Certain Legislative Acts of Ukraine on Expanding the Possibilities of SelfRepresentation in the Court of State Bodies, Authorities of the Autonomous Republic of Crimea, Local SelfGovernment Bodies, and Other Legal Entities Regardless of Their Order] (Verkhovna Rada Ukrainy) [(Verkhovna Rada of Ukraine)]. Ofitsiinyj sajt Verkhovnoyi Rady Ukrainy [The official website of the Verkhovna Rada of Ukraine]. <https://zakon.rada.gov.ua/laws/show/390-20> (2020, March, 06). [in Ukrainian].

\footnotetext{
1 Закон про прокуратуру 2014 (Верховна Рада України). Офіиійний сайт Верховної Ради Украӥни. $<$ http://zakon.rada.gov.ua/laws/show/1697-18> (2020, березень, 05).

2 Боков, Д.К. (2012). Гражданский иск прокурора в уголовном проиессе в защиту интересов государства: автореферат диссертации кандидата юридических наук. Москва, 7.
} 
5. Postanova Kabinetu Ministriv Ukrainy pro zatverdzhennia Zahalnoho polozhennia pro yurydychnu sluzhbu ministerstva, inshoho orhanu vykonavchoi vlady, derzhavnoho pidpryiemstva, ustanovy ta orhanizatsii 2008 [Resolution of the Cabinet of Ministers of Ukraine On Approval of the General Regulation on the Legal Service of the Ministry, Other Executive Body, State Enterprise, Institution and Organization] (Kabinet Ministriv Ukrainy) [(Cabinet of Ministers of Ukraine)]. Ofitsiinyj sajt Verkhovnoyi Rady Ukrainy [The official website of the Verkhovna Rada of Ukraine]. <http://zakon5.rada.gov.ua/laws/show/1040-2008-\%D0\%BF> (2020, March, 06). [in Ukrainian].

6. Kodeks Ukrainy z protsedur bankrutstva 2018 [Bankruptcy Code of Ukraine] (Verkhovna Rada Ukrainy) [(Verkhovna Rada of Ukraine)]. Ofitsiinyj sajt Verkhovnoyi Rady Ukrainy [The official website of the Verkhovna Rada of Ukraine]. <https://zakon.rada.gov.ua/laws/show/2597-197> (2020, March, 05). [in Ukrainian].

7. Zakon Ukrainy pro prokuraturu 2014 [Law of Ukraine On the Prosecutor's Office] (Verkhovna Rada Ukrainy) [(Verkhovna Rada of Ukraine)]. Ofitsiinyj sajt Verkhovnoyi Rady Ukrainy [The official website of the Verkhovna Rada of Ukraine]. <http://zakon.rada.gov.ua/laws/show/1697-18> (2020, March, 05). [in Ukrainian].

8. Bokov, D.K. (2012). Grajdanskiy isk prokurora v ugolovnom protsesse v zaschitu interesov gosudarstva [Civil suit of the prosecutor in the criminal process in defense of the interests of the state]: Avtoref. diss. na soisk. uchen. stepeni kand. yurid. nauk [Essay for the degree of candidate of law sciences]. Moscow. [in Russian]. 